\title{
VARIATIONS IN WEED FLORA AND THE DEGREE OF ITS TRANSFORMATION IN ECOLOGICAL AND EXTENSIVE CONVENTIONAL CEREAL CROPS IN SELECTED HABITATS OF THE BESKID WYSPOWY MOUNTAINS
}

\author{
Teresa Dąbkowska, Paulina Sygulska
}

\author{
Department of Agrotechnology and Agricultural Ecology, Agricultural University of Kraków \\ Al. Mickiewicza 21, 31-120 Kraków, Poland \\ e-mail: rrhochol@cyf-kr.edu.pl
}

Received: 10.01 .2012

\begin{abstract}
The aim of the present study was to determine the effect of production conditions, as influenced by habitat factors and farming system, on the geographical-historical spectrum of weed flora accompanying cereal crops and selected aspects of its transformations. The study was conducted in the period 2009-2011 in seven field habitats located in the municipality of Słopnice (Beskid Wyspowy Mountains). The study material consisted of 192 phytosociological relevés made using the Braun-Blanquet method in ecological and extensive conventional cereal crops. The obtained results are evidence of the numerical predominance of native species (spontaneophytes) over alien taxa in weed infestation, regardless of conditions. The dominant proportion of synanthropic spontaneophytes (apophytes) in weed infestation of fields proves the leading role of the process of apophytization and thus a small effect of anthropopressure on the status and transformations of the flora. Nevertheless, the alien flora, dominated by archeophytes, confirms the historical continuity of agricultural culture in the study area.

The parameters describing synanthropic transformations of arable flora, i.e. the anthropophytization, archaeophytization, kenophytization and modernization indices of this flora, do not show any significant differences resulting from production conditions. However, there are reasons that allow us to presume that the directions and intensity of transformations of the segetal flora in the study area are more determined by habitat conditions that ensure the ongoing co-occurrence of different land use forms and plant communities which are important for the maintenance of biological diversity and which strengthen the sustainability of the agricultural environment.
\end{abstract}

Key words: cereals, segetal flora, spontaneophytes, antropophytes, synanthropization indices, farming system, habitat conditions, Beskid Wyspowy Mountains

\section{INTRODUCTION}

The proportion of native and alien species in agricultural crops is a resultant of the effects of habitat factors, but it is also an outcome of the impact of the prevalent farming system and farming intensity. In particular, the authors investigating weed infestation in areas with adverse conditions for agricultural production have drawn their attention to the role of habitat, seeking in habitats the reasons for differences in the richness and geographical-historical spectrum of segetal floras as well as their susceptibility to anthropopressure-induced transformations (W ó j c i k, 1968; S t u p n icka-R odzynki ew icz, 1995; Hochół, 2001; Dąbkowska and Grabowska-Orzą$\mathrm{d}$ a $\mathrm{a}$, 2011). However, the reports showing the role of anthropogenic impacts, in particular farming intensity as a factor that determines the richness and species composition of arable flora, are evidence of the great complexity of this issue. The greater is production intensity, the stronger is this relationship, and production intensity is usually closely related to physiographic and soil conditions ( $\mathrm{S} \mathrm{t} \mathrm{u} \mathrm{p} \mathrm{n} \mathrm{i} \mathrm{cka-R} \mathrm{odz} \mathrm{y} \mathrm{n} \mathrm{ki} \mathrm{e} \mathrm{w} \mathrm{i} \mathrm{c} \mathrm{z}$ and Hochół, 2000; D ąbkow ska et al. 2007; Jezierska-Domaradzka and Kuźniewski, 2007; Ka peluszny and Haliniarz, 2007; R z y mow s ka and S krajna, 2011).

The increasing anthropopressure adversely affects flora resources, including arable flora. The loss of many species, especially archaeophytes, the disturbing phenomenon of encroachment of difficult to control taxa into crops or their increased occurrence, including taxa alien to the native flora, are the most frequently mentioned threats, in particular with regard to intensive 
farming systems (Kornaś, 1981; W a rcholińska, 1994; Albrecht, 1995; Sutcliffe and K a y, 2000; Trzcińs ka - T a cik, 2003a, b; S o ltys, 2006; B aessler and Klotz, 2006; Hyvönen and Huusela-Veistola, 2008; Kołaczkowska, 2008; B alcerkiewicz and P a w l a k, 2010; W ę gr z y n e k, 2010). Therefore, suggestions have been put forward to review the lists of threatened segetal species and even to protect them (Bomanowska, 2010; Siciński and Sie$\mathrm{radzki}, 2010)$. One of the chances for maintaining the diversity of segetal flora is extensive agricultural production, in particular ecological agriculture.

The aim of this study was to evaluate the effect of the ecological system and conventional extensive farming methods, including the use of synthetic mineral fertilizers and herbicides, on the geographical-historical spectrum and different aspects of transformations of weed flora accompanying cereal crops in selected field habitats with the same physiographic and soil conditions located in the Beskid Wyspowy Mountains.

\section{MATERIALS AND METHODS}

This study was conducted in the period 20092011 in the municipality of Słopnice, located within the area of the Beskid Wyspowy mesoregion, in Limanowa County. The study area is characterized by significant fragmentation of fields; the area of individual agricultural plots covered by the study did not exceed $1 \mathrm{ha}$, which is typical of southern Małopolska (Lesser Poland). Similarly to other regions of the Carpathian Mountains, habitat conditions in the study area are less favourable for intensive agriculture (K o peć , 1999). The farmland here adjoins lands with other long-established land uses, which is an important landscape value and which facilitates the fulfilment of the criteria of ecological agriculture that is developing intensively within the study area.

The ecological farms in which the present study was carried out were subject to inspection by the bodies carrying out certification of agricultural production for its compliance with the applicable European Union requirements of the Council Regulation (EC) No 834/2007 and the Council Regulation (EC) No 889/2008 (Council Regulation ..., 2007; Council Regulation ..., 2008). They exclude the use of synthetic fertilizers and plant protection products, and the farming methods that fulfil the above-mentioned requirements were used for a period of at least 5 years, in which the period of conversion preceding the award of the status of ecological farm should be included.

The other group of cereal crops investigated was located in farms with the same physiographic and soil conditions which used low-input extensive production methods. However, they differed from the certified ecological farms, among others, in the use of herbicides, which was found during field investigations on the basis of traces of their action or during interviews with the farmers, as well as in the occasional use of synthetic mineral fertilizers. These facts determined that the term "conventional" was adopted with respect to such sites. Most of the farmers, regardless of the production system used, declared that as a rule they used seed material from their own cereal crops or exchanged such seed material with their neighbours.

The production conditions for cereal crops and weed infestation of crops were determined by the physiographic and soil factors as well as by the agricultural production methods used (Table 1). The location within the area of the municipality as well as the variation in physiographic and soil conditions allowed us to designate seven study sites (habitats). The soil conditions in each of these habitats were identified in the field on the basis of agricultural soil maps at a scale of 1:5000 (Mapa glebowo-rolnicza..., 1981a, b). All designated habitats were located on flysch-derived soils, predominant in the Beskid Wyspowy Mountains. Geographical coordinates and altitude above sea level were determined with a Garmin GPSHAP 62S navigator, while the slope gradient on the basis of measurements made with a SUUNTO altimeter.

In each of the habitats, there were ecological and conventional crops next to each other in a quantity that allowed 12-15 phytosociological relevés to be obtained for each site in homogeneous conditions over the 3 -year study period. In practice, it meant that all cereal crops within the designated habitats were covered by the study in particular years. Among spring cereals, it was generally oats and its mixtures with spring barley, while winter crops were mainly represented by wheat and triticale. Due to the research-proven uniformity of weed flora accompanying various crops in mountainous conditions (K o r n a ś, 1968; H o c hó 1 , 2001), the phytosociological relevés from spring and winter cereal crops in the particular habitats were used together.

Altogether, 192 phytosociological relevés, made by the Braun-Blanquet method, were used in the study. The area of each relevé was about $100 \mathrm{~m}^{2}$ and relevés were made each year in the first 10-day period of July. Based on the material collected, we determined the constancy of each taxon within the identified habitats and under the particular farming systems as well as the coverage indices (P a w łow ski, 1972), which formed the basis for a separate study on the risk of weed infestation in crops.

For the needs of this study, a geo-historical classification of the identified flora was carried out using the assumptions made in the paper by $\mathrm{C} \mathrm{h} \mathrm{m} \mathrm{i} \mathrm{e} 1$ 
(2006). The list of all species found also includes their constancy and cover-abundance according to the Braun-Blanquet scale, as determined under the study conditions. Native species were distinguished - spontaneophytes (S), represented by non-synanthropic spontaneophytes (Sp), i.e. taxa occurring almost exclusively in natural and semi-natural habitats, semi-synanthropic spontaneophytes (Sp/Ap) - native species that are found with a high frequency in semi-natural and anthropogenic communities, as well as apophytes (Ap), i.e. taxa of local origin which occur exclusively or almost exclusively in semi-natural and anthropogenic habitats. The alien elements identified in the studied flora are anthropophytes (A), i.e. introduced taxa that remain in the native flora due to human activity. They are mainly represented by naturalized species: i.e. archaeophytes (Ar), which were introduced before the end of the 15th century, and those that were introduced and naturalized in more recent times, i.e. kenophytes $(\mathrm{Kn})$. We also recorded a single case of a species included in diaphytes (D) - taxa that occur periodically without conscious human intervention; in the study area, it related to the species Juglans regia L. which was found at the seedling stage.

To evaluate the effect of production conditions on the arable flora of the study area, relationships were determined between the groups of species representing different origins and a different status of naturalization in each type of crop in the identified habitats. These relationships are presented in the form of indices expressing transformations in the segetal flora. Each of them, except for the modernization index, represents the percentage contribution of a particular group (or groups) of taxa being a sum of spontaneophytes (S) and anthropophytes (A) in the total number of species found under specific production conditions. Values of the individual indices are calculated in the same way as it is done for the synanthropization index $\left(S_{\mathrm{w}}\right)$, which is shown below. It defines the percentage of apophytes (Ap) and anthropophytes (A) in the total number of species, as expressed by the following formula (Chmi e 1, 2006):

$$
S_{w}=\frac{A p+A}{S+A} \times 100 \%
$$

Moreover, the paper presents the following indices:

- The apophytization index $\left(A p_{w}\right)$ reflecting the percentage of apophytes (Ap) in the total number of species found;

- The total anthropophytization index $\left(\mathrm{A}_{\mathrm{n}}\right)$, which defines the percentage of anthropophytes (A) in the total number of species found;
- The archaeophytization index $\left(\mathrm{A}_{\mathrm{r}}\right)$, expressed as the percentage of archaeophytes (Ar) in the total number of species found;

- The kenophytization index $\left(K_{n}\right)$, showing the percentage of kenophytes $(\mathrm{Kn})$ in the total number of species found;

- The modernization index (M), expressing the percentage of kenophytes $(\mathrm{Kn})$ in the flora of permanently naturalized anthropophytes (Ar $+\mathrm{Kn}$ ).

To test the hypothesis on the effect of farming system as well as physiographic and soil conditions of the designated habitats on the investigated characteristics of the flora, non-parametric tests were employed: the Mann-Whitney U test and the Kruskal-Wallis test (StatSoft, 2011). Since the significance of the above hypotheses was not confirmed, the obtained results were presented descriptively in order to emphasize the observed correlations showing the importance of the relationship between the type of habitat and the character of arable flora. Species nomenclature followed Mirek et al. (2002).

\section{RESULTS}

The identified field habitats are characterized by varying richness of weed species representing different origins (Fig. 1). In each of them, the group of native flora representatives (spontaneophytes) exceeds significantly the number of species of alien origin (anthropophytes). This can be seen in particular in habitat 5 , the least suitable for cropping due to its physiographic and soil conditions, which was found to have the richest list of local flora representatives. This indicates the greater importance of habitat conditions than of the farming system for the proportions between the identified groups of taxa. The local taxa were also marked by a greater, although statistically insignificant, variation caused by the farming system, which is evidenced by the dispersion of the values, whereas in the case of anthropophytes none of the study assumptions considered was confirmed.

Table 2 shows a list of species found in not fewer than four designated study sites. It includes the constancy and cover-abundance of species according to the Braun-Blanquet scale, as determined for each of them at the identified sites. This list is complemented by a summary of species occurring at a lower number at the sites in question (1-3), usually with the cover-abundance from "+" to " $r$ " and a low constancy degree, which was omitted in the list.

Species of local origin (90 taxa) are represented within the study area primarily by synanthropic spontaneophytes (apophytes), whereas in the group of anthropophytes archaeophytes are largely predominant 
(36 taxa), forming the core of the flora of alien origin permanently naturalized within the study area. The same or similar frequency of occurrence and cover-abundance in the case of many taxa differing in their origin are evidence of the lack of effect of agricultural production conditions on the arable flora studied.

The much higher values of the synanthropization index (Sw) compared to the apophytization index (Apw) are evidence of the effective impact of even extensive farming methods on the composition of segetal flora communities (Fig. 2). However, the values of this index are very similar, regardless of the location of crops investigated. The values of the apophytization index are at similar levels, but in habitat 5 the importance of the process maintaining the predominance of the local species in weed infestation is more evident. This proves the greater predisposition of this location to arable use different than the existing one.

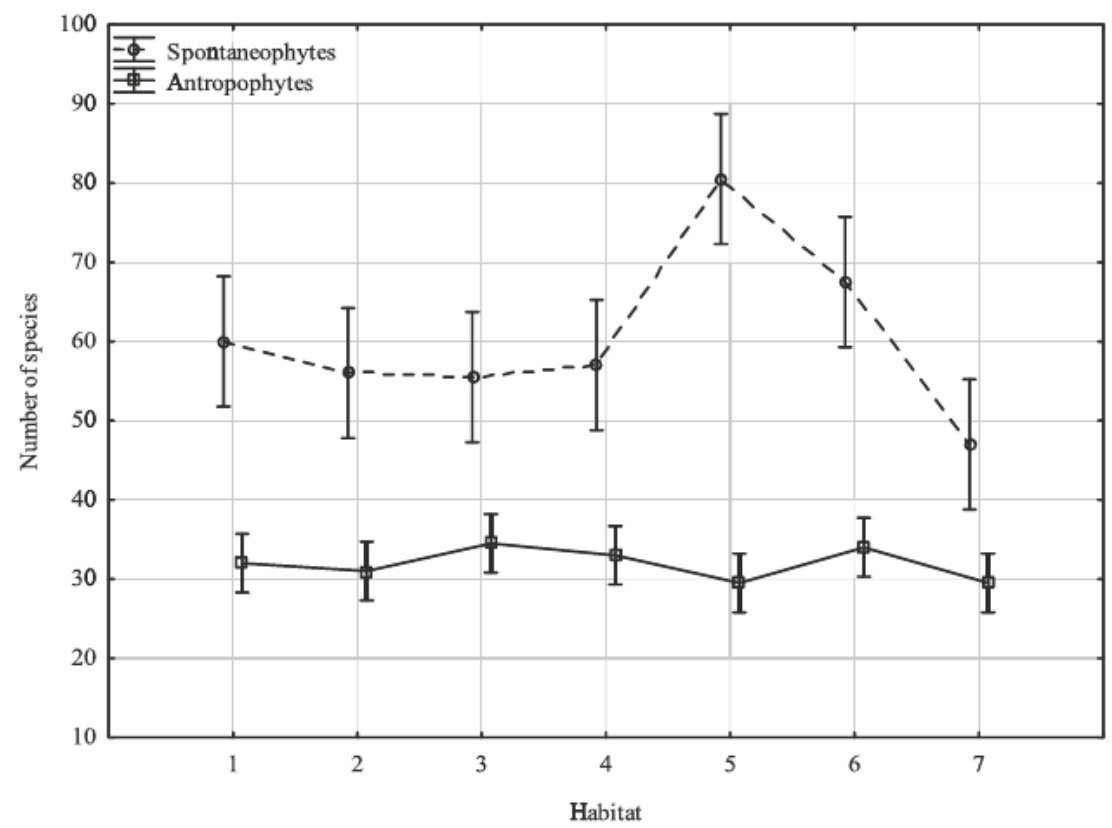

Fig. 1. Richness of species of different origin in segetal flora of investigated habitats

(In Figures 1-4: The vertical bars are a measure of the dispersion of values due to farming system)

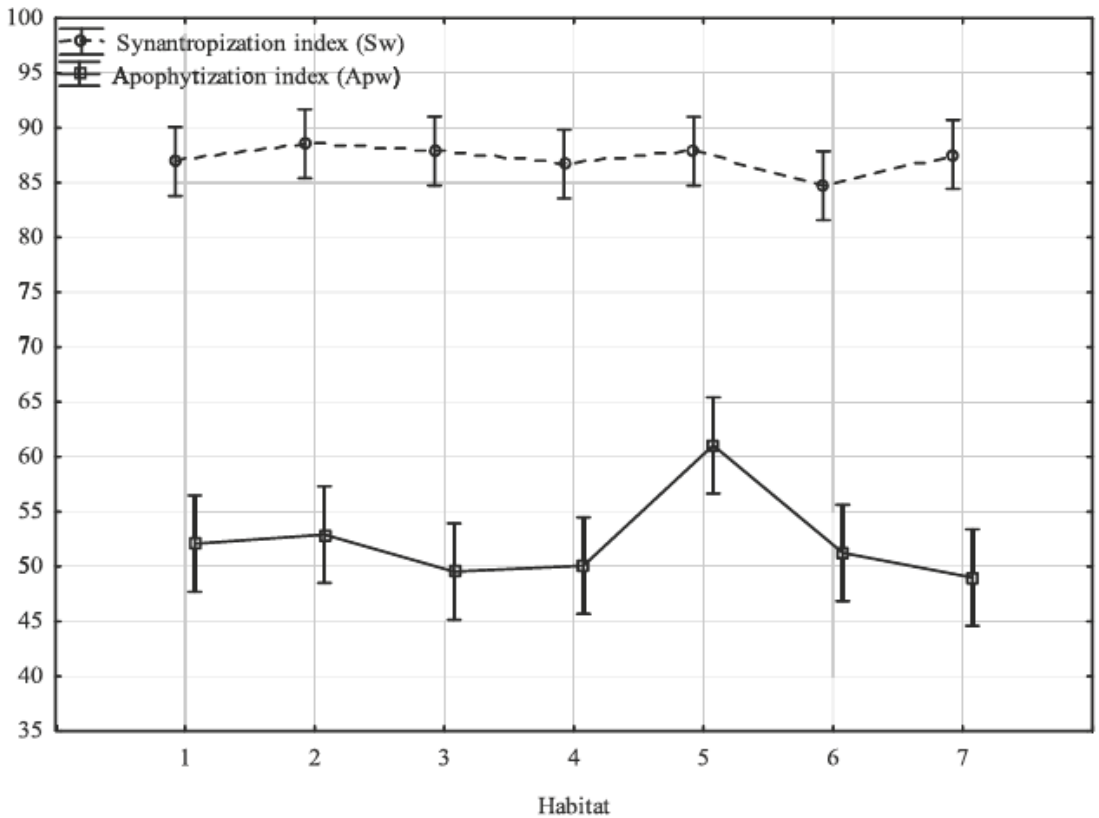

Fig. 2. Synanthropization index (Sw) and apophytization index (Apw) of segetal flora depending on habitat conditions 
The values of the anthropophytization (An) and archaeophytization (Ar) indices, reflecting the contribution of geographically alien elements in the studied flora, including the taxa that have been naturalized for the longest time (archaeophytes), are similar in the individual habitats (Fig. 3). The higher values of the former parameter generally apply to the habitats more favourable for agricultural production due to their soil conditions and/or location in the terrain (see Table 1). The lack of differences in both parameters confirms that the capacity which the conventional system has, even in its extensive version, is poorly used in the study area or that there is not much attention paid to the effectiveness of weed control treatments, including herbicide application, compared to ecological production conditions. The values of both indicators in question determined for habitat 5 differed substantially from the other values, which is yet another argument although not confirmed statistically - proving the low usefulness of this location for arable use.

Table 1

Characteristics of the study area

\begin{tabular}{|c|c|c|c|c|c|c|c|}
\hline \multirow{2}{*}{ Habitat } & \multirow{2}{*}{$\begin{array}{l}\text { Location and } \\
\text { GPS coordinates }\end{array}$} & \multirow{2}{*}{ Soil } & \multirow{2}{*}{$\begin{array}{l}\text { Altitude } \\
\text { (m a.s.l.) }\end{array}$} & \multirow{2}{*}{ Exposure } & \multirow{2}{*}{ Slope $\left(^{\circ}\right)$} & \multicolumn{2}{|c|}{$\begin{array}{l}\text { Number of } \\
\text { phytosociological relevés }\end{array}$} \\
\hline & & & & & & $\mathrm{E}^{*}$ & $\mathrm{~K}^{*}$ \\
\hline 1 & $\begin{array}{c}\text { Hajdówki } \\
\text { 4942’32.6”N } \\
20^{\circ} 20^{\prime} 24.8 ’ \mathrm{E}\end{array}$ & $\begin{array}{c}10 \mathrm{Bw} \square \\
\text { heavy dusty loam }\end{array}$ & $450-470$ & $\mathrm{E}, \mathrm{SE}$ & $1-3$ & 12 & $12(5) * *$ \\
\hline 2 & $\begin{array}{c}\text { Hajdówki } \\
\text { 4942’29.9”N } \\
\text { 20²0'10.6’E }\end{array}$ & $\begin{array}{l}12 \mathrm{Bw} \square \\
\text { heavy dusty loam }\end{array}$ & $470-480$ & E & $1-3$ & 12 & 12(11) \\
\hline 3 & $\begin{array}{c}\text { Przylaski } \\
49^{\circ} 42^{\prime} 41.2{ }^{\prime \prime} \mathrm{N} \\
20^{\circ} 21 ' 56.5 ' \mathrm{E} \\
49^{\circ} 42^{\prime} 10.8{ }^{\prime \prime} \mathrm{N} \\
20^{\circ} 21^{\prime} 41.8^{\prime \prime} \mathrm{E}\end{array}$ & $\begin{array}{c}11 \mathrm{Bw} \\
\text { heavy loam }\end{array}$ & $480-500$ & S, SW & $1-3$ & 15 & 15(14) \\
\hline 4 & $\begin{array}{c}\text { Wójtostwo } \\
\text { i Zaświercze } \\
49^{\circ} 42^{\prime} 02.2{ }^{\prime} \mathrm{N} \\
20^{\circ} 20^{\prime} 09.5{ }^{\prime \prime} \mathrm{E} \\
49^{\circ} 41^{\prime} 48.77^{\prime \prime} \mathrm{N} \\
20^{\circ} 19^{\prime} 18.0 \text { 'E }\end{array}$ & $\begin{array}{l}12 \mathrm{Bw} \\
\text { silty clay }\end{array}$ & $510-530$ & $\mathrm{E}, \mathrm{NE}$ & $3-7$ & 15 & $15(9)$ \\
\hline 5 & $\begin{array}{c}\text { Jurki } \\
\text { 4940'32.0”N } \\
\text { 20ş18'57.6”'E } \\
49^{\circ} 40 \text { '26.4”'N } \\
20^{\circ} 18^{\prime} 51.1 \text { '” }\end{array}$ & $\begin{array}{l}14 \mathrm{Bw} \\
\text { medium dusty loam } \\
\text { heavy dusty loam }\end{array}$ & $540-570$ & $\mathrm{E}, \mathrm{NE}$ & $6-9$ & 15 & 15(11) \\
\hline 6 & $\begin{array}{c}\text { Zagrody } \\
49^{\circ} 41^{\prime} 10.1 \text { '” } \\
20^{\circ} 19^{\prime} 00.1{ }^{\prime \prime} \mathrm{E} \\
49^{\circ} 41 ' 17.3 ” \mathrm{~N} \\
20^{\circ} 19^{\prime} 23.0{ }^{\prime} \mathrm{E}\end{array}$ & $\begin{array}{c}13 \mathrm{Bw} \\
\text { clay and clay forms }\end{array}$ & $570-620$ & $\mathrm{~S}, \mathrm{SE}$ & $3-7$ & 15 & 15(11) \\
\hline 7 & $\begin{array}{c}\text { Barszcze } \\
49^{\circ} 40^{\prime} 18.8^{\prime \prime} \mathrm{N} \\
20^{\circ} 22^{\prime} 18.1{ }^{\prime \prime} \mathrm{E}\end{array}$ & $\begin{array}{l}13 \mathrm{Bw} \square \\
\text { clay and clay forms }\end{array}$ & $610-620$ & $\begin{array}{l}\text { Lw.***; } \\
\text { S; SW }\end{array}$ & $0 ; 1-3$ & 12 & $12(9)$ \\
\hline
\end{tabular}




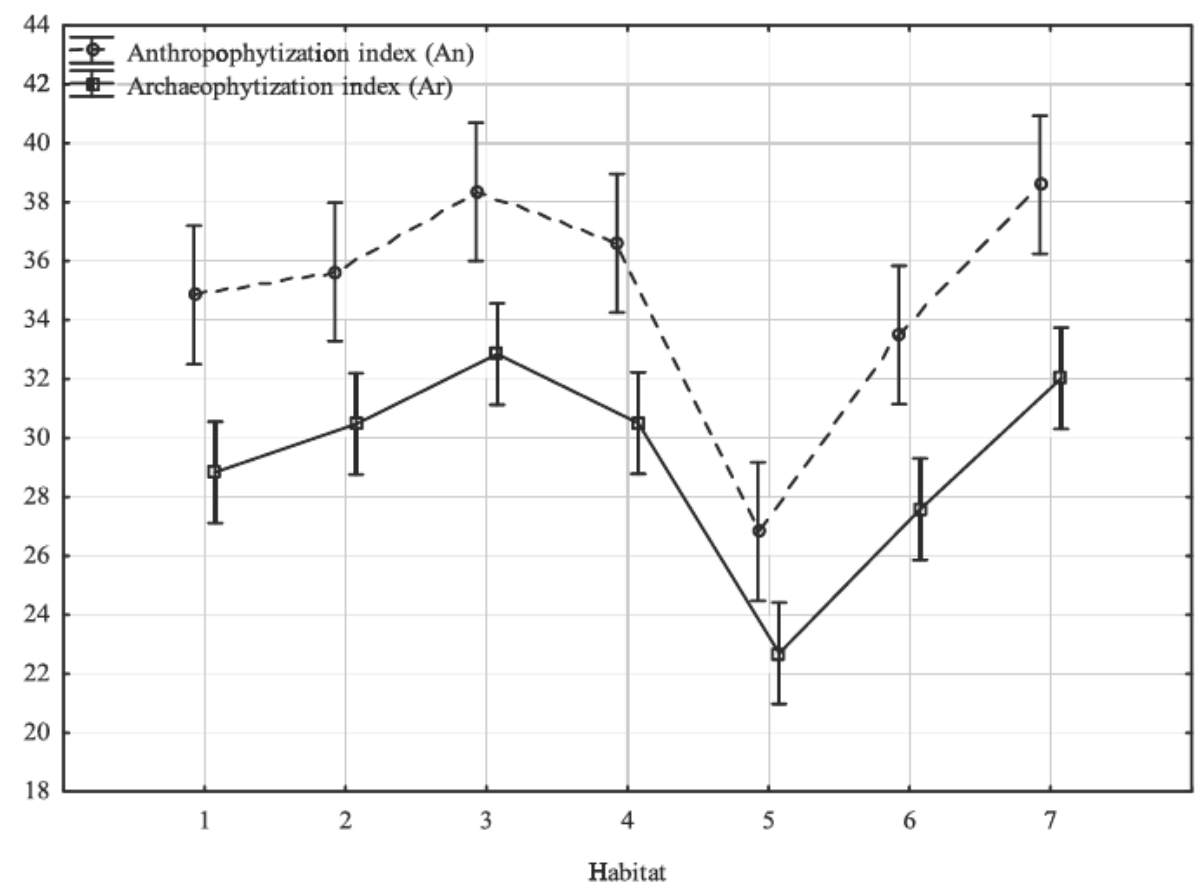

Fig. 3. Anthropophytization index (An) and archaeophytization index (Ar) of segetal flora depending on habitat conditions

The values of the kenophytization index (Kn) of the flora and, as a consequence, its modernization index (M), evidencing the modern penetration of alien species (mainly epecophytes) into crops (Fig. 4), demonstrate the small scale of this phenomenon within the study area and the limited susceptibility of crops in this conditions to accept this group of newcomers. At the same time, the former of these parameters seems to be modified within the study area by farming system more clearly than the other parameters, which is evidenced by a signficant dispersion of the empirical values. The absence of a uniform trend in the mean values of the kenophytization index within the study area may however prove that the intensity of this process is determined by the history of farming carried out under specific habitat conditions.

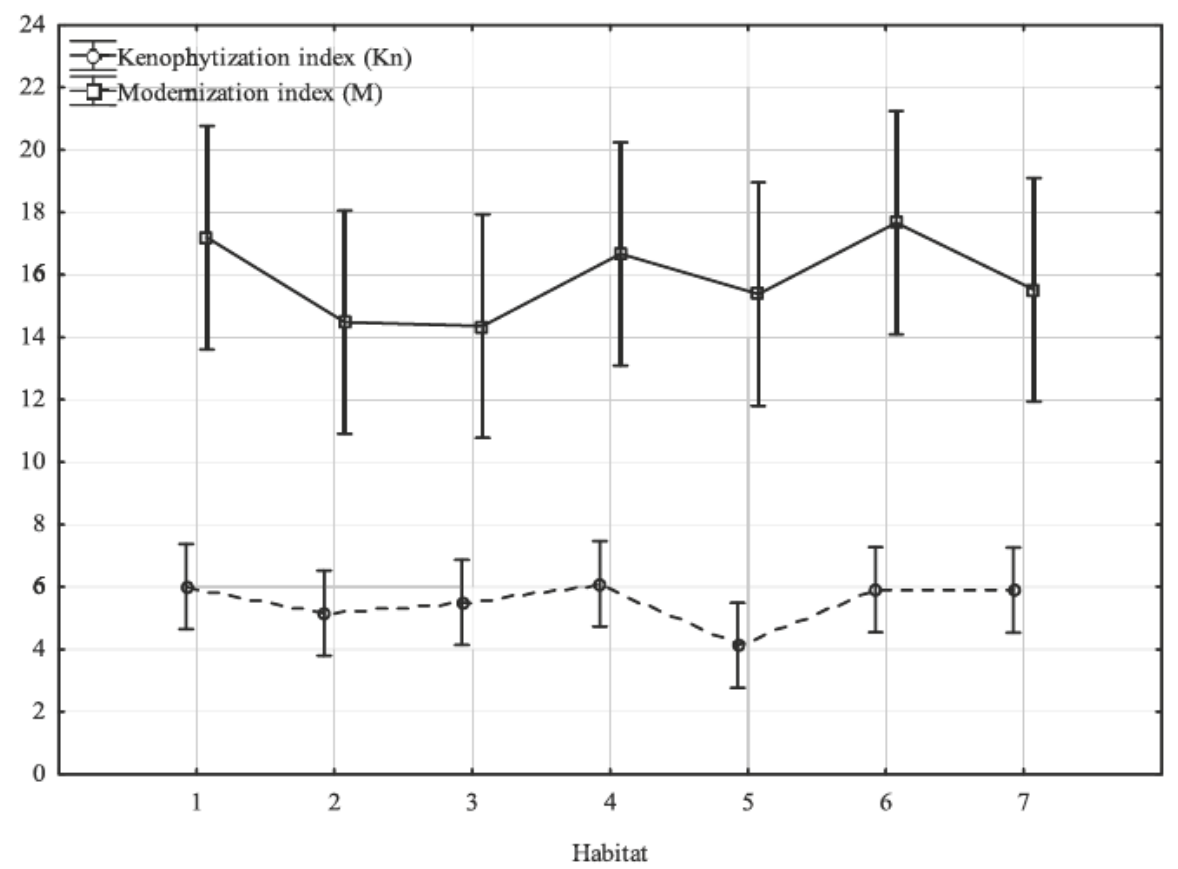

Fig. 4. Kenophytization index $(\mathrm{Kn})$ and modernization index (M) of segetal flora depending on habitat conditions 


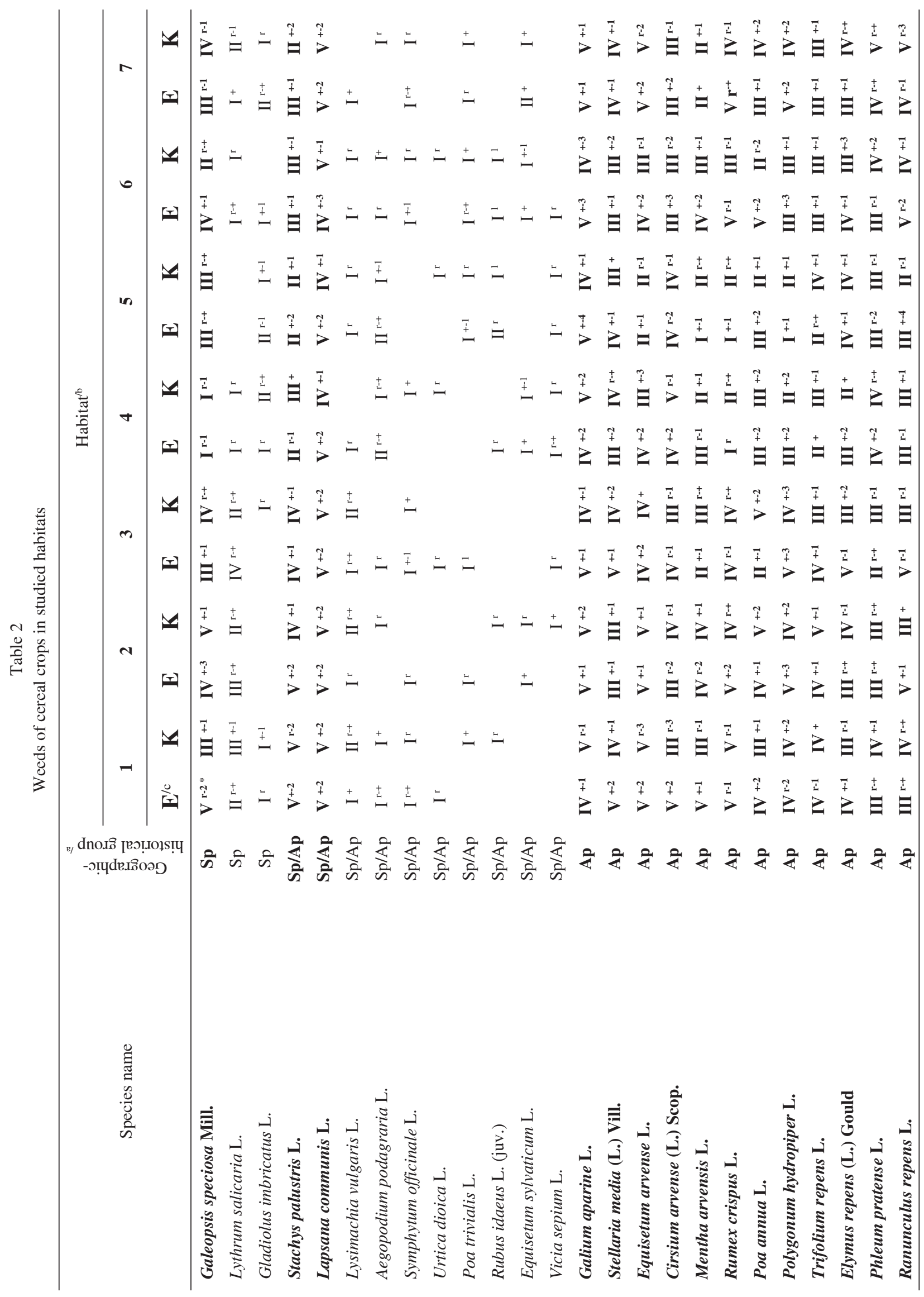




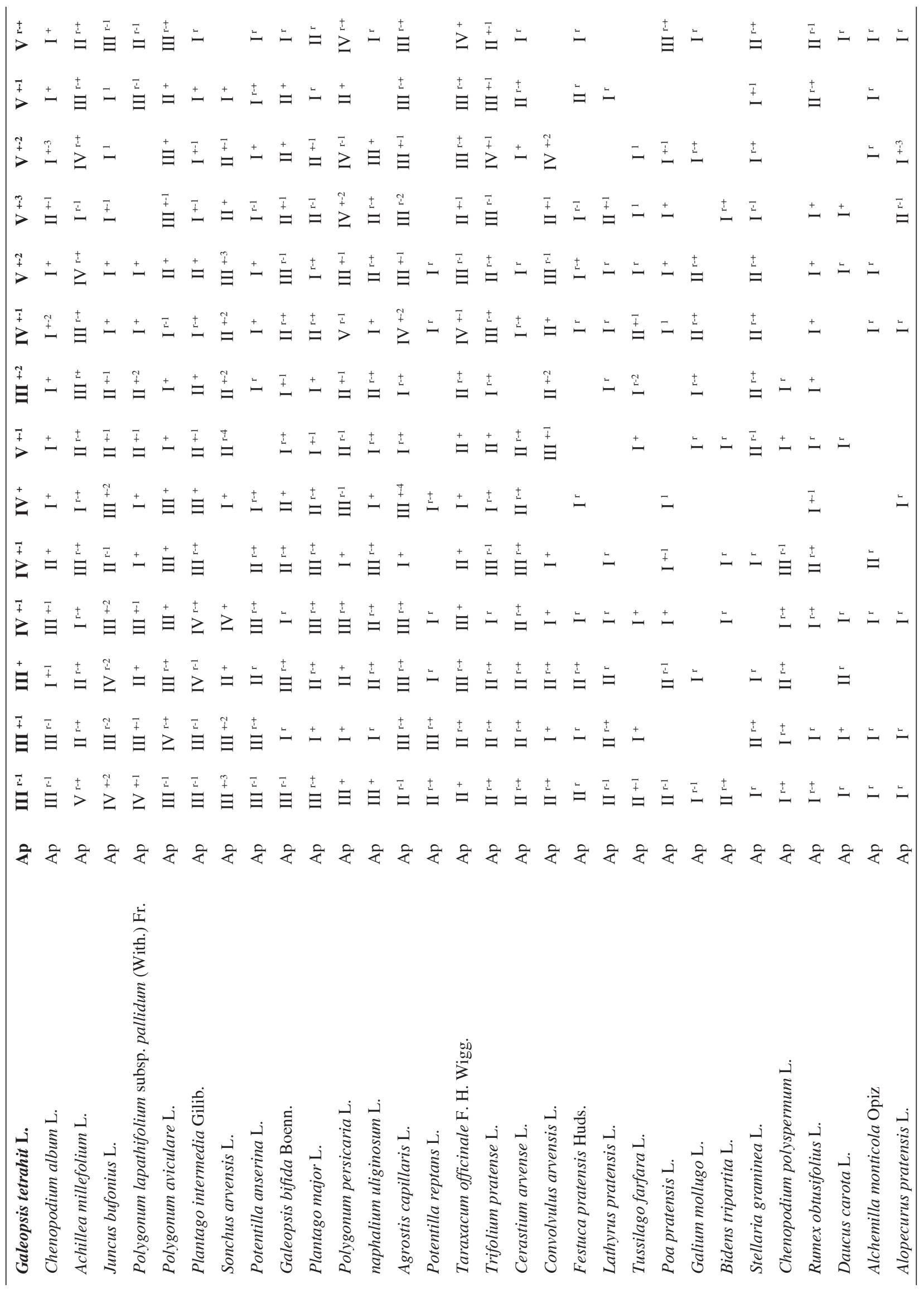




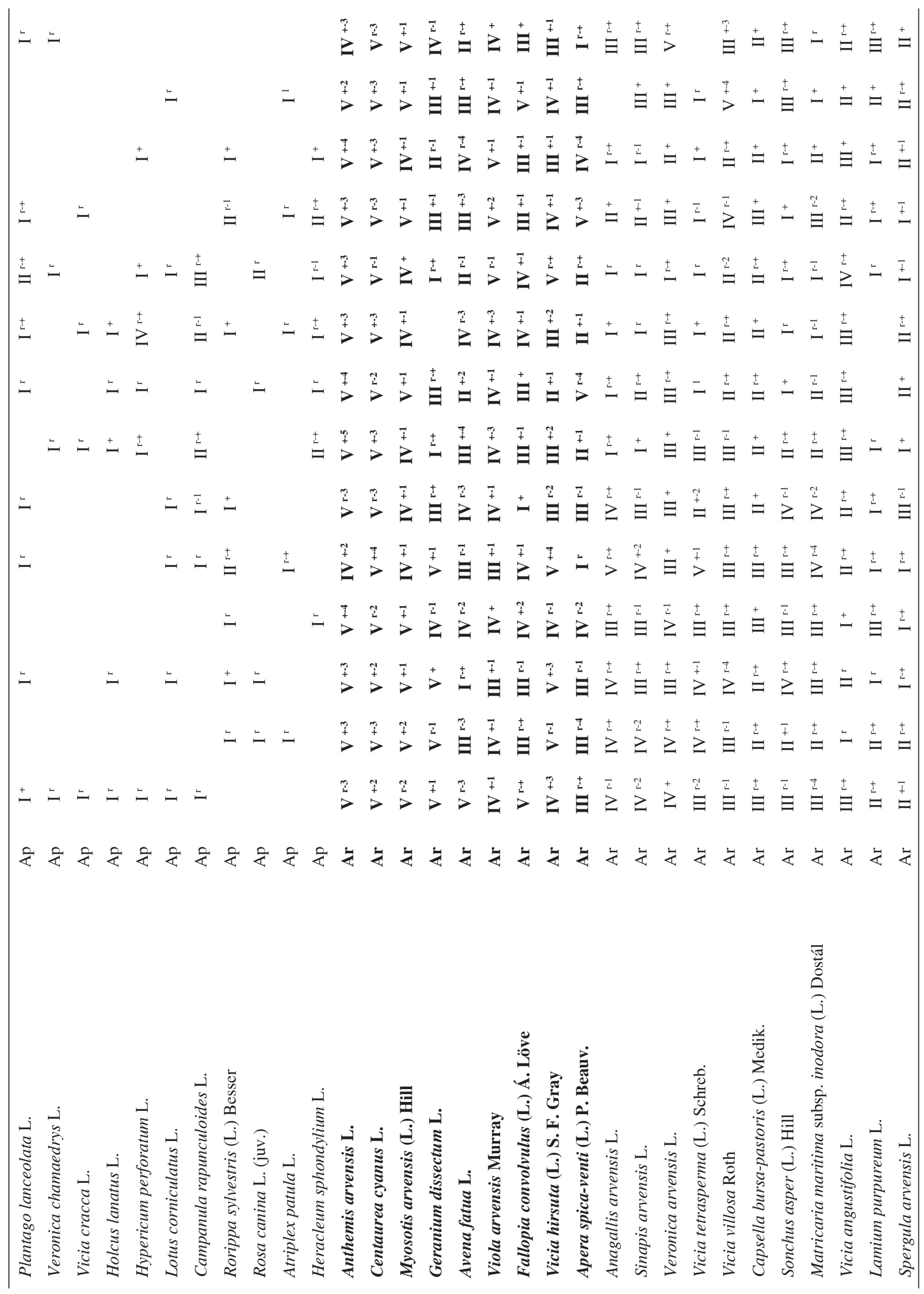




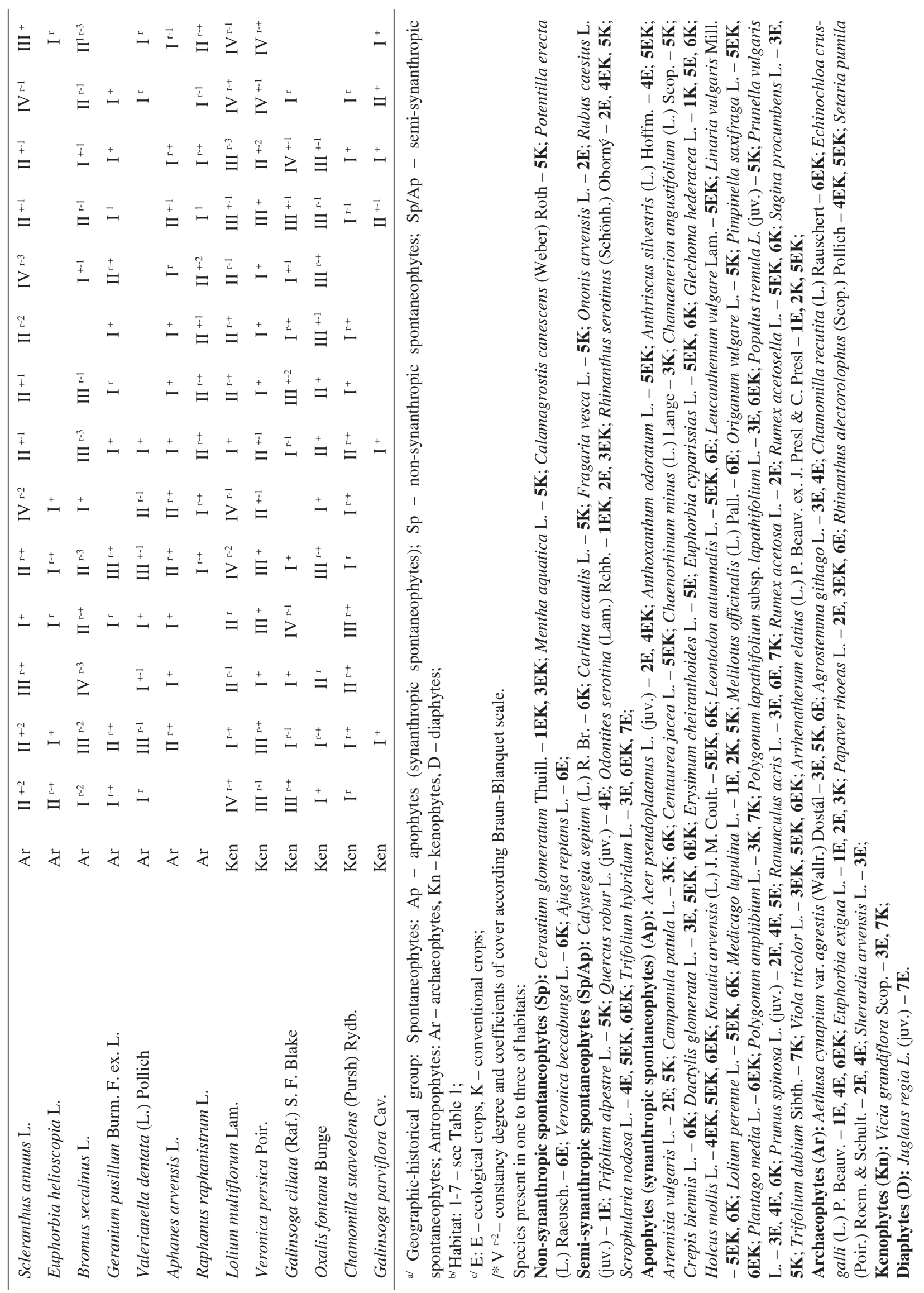




\section{DISCUSSION}

The results of this study prove the low variation of the geographical-historical spectrum of the studied floras. Regardless of production conditions, native plants, spontaneophytes, form the core of weed infestation in all the habitats. This confirms the low usefulness of the investigated habitats as arable land, similarly as it is in other regions of the Western Carpathians (K o p e ć, 1999). The physiographic and soil conditions here can determine the greater success of the local flora, even in the case of more intensive farming methods. Similar results with regard to cereal cropping using the conventional system in the area of the Beskid Wyspowy Mountains were earlier presented by Hochół (2001), who demonstrated a strong relationship of segetal flora, its biological structure and geographical-historical spectrum with the location of fields in the terrain. In her opinion, the strong dominance of species of local origin in weed infestation of crops is evidence of the usefulness of the habitats for arable use other than conventional tillage farming and the knowledge of the geographical-historical spectrum of the segetal flora should be useful for the optimisation of soil use in habitats unfavourable to cropping.

The presented correlations are in agreement with the results of the study of B alcerkiewicz and Pawlak (2010) who showed that native taxa frequently accounted for more than $50 \%$ of species occurring in the phytocoenoses of cereal crops, in particular under extensive farming conditions. In their opinion, the number of spontaneophytes and their importance are clearly higher there, while these species play a marginal role in communities developing under strong anthropopressure conditions. Spontaneophytes are also an important element of field phytocoenoses developing in extreme habitat conditions, e.g. excessively moist habitats (K r a w i e c ow a, 1968; W ój cik, 1968; K or n aś, 1981;).

Results different than those presented above were obtained in the conditions prevailing in the Opole region (Jezierska-Domaradzka and Kuź-

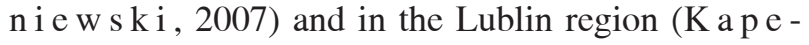
luszny and Haliniarz, 2007), which are more suitable for agriculture and where the proportion of native species in weed infestation was not more than half of resources of the identified arable floras. This correlation applies even more clearly to Wielkopolska (Greater Poland) where the percentage of native species is only about $35 \%$, whereas archaeophytes account for as much as $50 \%$ and kenophytes for nearly $15 \%$ of the total number of real segetal flora species ( $\mathrm{L}$ a t o w s k i et al. 2010).

The differences, statistically not confirmed, in the level of synanthropization of the segetal flora as influenced by farming systems similar in terms of their intensity show a similar or low level of anthropopressure, which is also contributed by the less favourable physiographic and soil conditions of the study area. In their comparative study, D a b k o w s k a and Grabowska-Orządała (2011) presented similar values of this index for the flora of conventional crops in the habitats of Pogórze Wielickie (Wieliczka Foothills), thus habitats located in an area more favourable to agriculture, and much lower values for some other parts of the Beskid Wyspowy and Gorce Mountains where agriculture is more extensive.

Assuming that flora synanthropization is a resultant of two opposite processes: apophytization and anthropophytization (Kornaś, 1981; Chmiel, 1993), one may express the conviction that currently the former process determines the level of transformation of the arable floras in question. It is probably attributable to much richer flora resources of spontaneophytes, mainly apophytes, which are much better adapted to the local physiographic and soil conditions than the cultivated species and less numerous, typical segetal weeds (anthropophytes). B a l c e r ki e w i c z and P a w la k (2010) express a view that many native species find in fields more suitable conditions than in the communities from which they originate, and as a result of that they are troublesome crop weeds. This applies especially to apophytes, which are common within the study area under each of the farming systems investigated, such as: Cirsium arvense, Galium aparine, Stellaria media, Chenopodium album, Elymus repens, or Equisetum arvense. Due to the favourable habitat conditions, their list is much longer in the study area (see Table 2).

The opinion of different authors (Stupnicka-Rodzynkiewicz and Hochól, 2000; Dąbkowska et al. 2007; Feledyn-Szewc z y k, 2008) concerning the special role of ecological crops for the maintenance of the richness and diversity of segetal species, in particular archaeophytes, was not confirmed unambiguously under the conditions of this study, but this is no ground for questioning the correctness of this opinion. The above-mentioned authors were based on comparisons of farming systems differing in intensity more than it was the case in the present study. In the opinion of R o s c h e w i t $\mathrm{z}$ et al. (2005), the ecological farming system more clearly affects weed species diversity in the conditions of homogeneous landscapes. On the other hand, in the case of a mosaic of habitats (and thus in the case of the diversity of plant communities as it was in the study area), the variation in the flora caused by the farming system is not evident. The similar values of the archaeophytization index of the cereal weed flora show that the differences in intensity of the compared farming systems within the study area come down to theoretical assumptions, 
whereas in agricultural practice the level of anthropopressure related to them is similar. This may be evidence that the investigated conventional farms use more extensive production practices than it might be expected, even in less favourable conditions for agriculture, or they ineffectively implement the measures envisaged for this type of production.

In each of the habitats studied, archaeophytes have a several times higher percentage in the flora of alien origin than kenophytes, similarly to other regions of the Carpathian Mountains (H o c h ó 1, 2001; D ą b kowska and Grabowska-Orządała, 2011). This shows the historical continuity of agricultural culture in the study area and, at the same time, is evidence of the slow pace of modern transformations in the local segetal flora, which is also confirmed by the low values of the kenophytization index, in particular the flora modernization index. The slightly higher values of the parameter representing the "rejuvenation" of the alien flora was calculated for the habitats situated in locations with more favourable conditions for cropping as well as more accessible from farm buildings and in terms of transport due to the character of their topography. This confirms the inevitability of transformations of arable flora, which is also mentioned by other authors (Stupnicka-Rodzynkiewicz, 1995; Chmiel, 2006; Dąbkowska and Grabow$\mathrm{ska}-\mathrm{Orzadała}, 2011$ ), and their greater intensity in the conditions more susceptible to anthropogenic disturbances.

The conviction about the low level of anthropopressure within the study area is also based on the occurrence, under both farming systems, of archaeophytes such as, in particular, Bromus secalinus, Centaurea cyanus, or Sinapis arvensis, which represent species that have been long mentioned as threatened species in intensive agriculture areas (K or n a ś, 1981; A 1 b recht, 1995; W a r cholińska, 1994; B o manowska, 2010; Siciński and Sieradzki, 2010). This opinion is also substantiated by the occurrence of dangerous grass species (Apera spica-venti and Avena fatua) in the study area, regardless of production conditions, which systematically increase their importance in the southern part of the country ( $\mathrm{Ho}$ chół, 2001; Dąbkowska and $\mathrm{Łabza}, 2010$ ). Their frequency and intensity of occurrence also in conventional cereal crops are evidence of the lack of regular use or inappropriate selection of herbicides, which is not justified even by the extensive character of the production methods used.

To sum up, one can conclude that the study area, due to its habitat specificity, different land use forms, the maintenance of traditional, extensive farming systems in conventional agriculture, and the growing interest in ecological production methods, is an enclave that provides a richness of native synanthropic flora. This also provides an opportunity for maintaining the diversity of representatives of the oldest group of anthropophytes threatened in field habitats in other regions of Poland.

\section{Acknowledgements}

Research supported by the Ministry of Science and Higher Education of Poland as the part of statutory activities of Department of Agrotechnology and Agricultural Ecology, Agricultural University of Krakov.

\section{Autors' contributions}

The following declarations about authors' contributions to the research have been made: TD, PS; field research: TD, PS; data analyses: TD, PS; writing the manuscript: TD; post-reviews corrected version of manuscript: TD.

\section{REFERENCES}

A lbrecht H. 1995. Changes in the arable weed flora of Germany during last five decades. Proc. $9^{\text {th }}$ EWRS Symp. "Challenges for weed science in a changing Europe", Budapest, 10-12.VII.1995: 41-48.

Baessler C., Klotz S. 2006. Effects of changes in agricultural land-use on landscape structure and arable weed vegetation over the last 50 years. Agric., Ecosyst. Environ. 115: 43-50. http://dx.doi.org/10.1016/j.agee. 2005.12.007

Balcerkiewicz St., Pawlak G.2010. Spontaneofity w zbiorowiskach segetalnych Polski. / Native plant species (spontaneophytes) in the segetal communities of Poland. Fragm. Agron. 27(3): 7-19. (in Polish)

Bomanowska A. 2010. Threat to arable weeds in Poland in the light of national and regional red lists. Plant Breed. Seed Sci. 61: 55-74. http://dx.doi.org/10.2478/v101 29-010-0013-7

Ch miel J. 1993. Flora roślin naczyniowych wschodniej części Pojezierza Gnieźnieńskiego i jej antropogeniczne przeobrażenia w wieku XIX i XX. / Flora of vascular plants of the eastern part of the Gniezno Lake District and its transformation under the influence of man in the $19^{\text {th }}$ and $20^{\text {th }}$ centuries. Cz. 1. Prace Zakładu Taksonomii Roślin UAM w Poznaniu, 1, Wyd. Sorus, Poznań: 202. (in Polish)

Ch miel J. 2006. Zróżnicowanie przestrzenne flory jako podstawa ochrony przyrody w krajobrazie rolniczym. / Spatial diversity of flora as a basis for nature conservancy in the agricultural landscape. Prace Zakładu Taksonomii Roślin UAM w Poznaniu, 14, Bogucki Wydawnictwo Naukowe, Poznań: 250. (in Polish)

Dąbkowska T., Grabowska-Orządała M. 2011. Flora segetalna upraw zbóż w siedliskach o niekorzystnych warunkach gospodarowania na terenie Zewnętrz- 
nych Karpat Zachodnich. Cz. 2. Przeobrażenia antropogeniczne flory segetalnej upraw zbóż w siedliskach o niekorzystnych warunkach gospodarowania. / Segetal flora of cereal crops in habitats of the outer Western Carpathians characterized by unfavourable farming conditions. Part 2. Anthropogenic transformations in segetal flora of cereal crops in habitats characterized by unfavourable farming conditions. Zesz. Probl. Post. Nauk Rol. 559: 33-41. (in Polish)

Dąbkowska T., Łabza T. 2010. Gatunki z rodziny Poaceae w uprawach zbóż na wybranych siedliskach Polski południowej w ostatnich 25 latach (1981-2006). / Species from Poaceae family in cereals in selected habitats of southern Poland over the last 25 years (1981-2006). Fragm. Agron. 27(2): 47-59. (in Polish)

Dąbkowska T., Stupnicka-Rodzynkiewicz E., Łabza T. 2007. Zachwaszczenie upraw zbóż w gospodarstwach ekologicznym, konwencjonalnym i intensywnym na wybranych przykładach z Małopolski. / Weed infestation of cereals in organic, conventional and intensive farms in Małopolska region. Pam. Puław. 145: 5-15. (in Polish)

Feledyn-Szewczyk B. 2008. The changes of biodiversity of weed flora in organic system in the years 1996-2007. J. Res. Appl. Agric. Engng, 53(3): 63-68.

Hochół T. 2001. Flora i zbiorowiska chwastów zbóż w Beskidzie Wyspowym w zależności od usytuowania siedlisk w rzeźbie terenu. / Segetal flora and communities in the Beskid Wyspowy Mts. depending on habitat location in the area relief. Fragm. Agron. 3(71): 7-122. (in Polish)

Hyvönen T., Huusela-Veistola E., 2008. Arable weeds as indicators of agricultural intensity - a case of study from Finland. Biol. Conserv. 141(11): 2857-2864. http://dx.doi.org/10.1016\%2Fj.biocon.2008.08.022

Jezierska-Domaradzka A., Kuźniewski E. 2007. Zachwaszczenie upraw zbóż na polach wybranych gospodarstw ekologicznych i tradycyjnych Opolszczyzny. / Weed infestation of cereals in selected organic and conventional farms in Opole region. Pam. Puław. 145: 115-122. (in Polish)

Kapeluszny J., Haliniarz M. 2007. Flora chwastów w gospodarstwach intensywnych oraz niestosujących herbicydów na glebach rędzinowych Lubelszczyzny. / Flora of weeds in the farms with intensive degree of chemical treatment and herbicides-free on rendzina soils in the Lublin region. Pam. Puław. 145: 123-131. (in Polish)

Kołaczkowska E. 2008. Inwazje obcych gatunków roślin - problem naukowy i praktyczny. / Invasions of alien plant species - a scientific and conservation problem. Prz. Geogr. 80(1): 55-73. (in Polish)

Kopeć S. 1999. Rolnictwo Karpat Zachodnich na przykładzie Beskidu Wyspowego i Żywieckiego. / Agriculture of Western Carpathians on example of Wyspowy and Żywiecki Beskids. Probl. Zagosp. Ziem Górs. 45: 7381. (in Polish)
Kornaś J ., 1981. Oddziaływanie człowieka na florę: mechanizmy i konsekwencje. Wiad. Bot. 25(3): 165-182. (in Polish)

Kornaś J. 1968. Zespoły roślinne Gorców. II. Zespoły synantropijne. / Plant communities of the Gorce Mts. (Polish Western Carpathians). II. Synanthropic communities. Fragm. Flor. et Geobot. 15(1): 83-124. (in Polish)

Krawiecowa A. 1968. Udział apofitów i antropofitów w spektrum geograficznym flory Gór Opawskich (Sudety Wschodnie). / The participation of apophytes and anthropophytes in the geographical spectrum of the flora of the Opawa Mountains (E-Sudetes). [In:] J.B. Faliński (ed.). Synantropizacja szaty roślinnej. I. Neofityzm i apofityzm. Mat. Zakł. Fitosocj. Stos. UW, WarszawaBiałowieża, 25: 97-107. (in Polish)

Latowski K., Chmiel J., Jackowiak B., Żukowski W. 2010. Udział antropofitów we florze segetalnej Wielkopolski. / Participation of anthropophytes in the segetal flora of Wielkopolska. Fragm. Agron. 27(3): 103-111. (in Polish)

Mapa glebowo-rolnicza w skali 1:5000 wraz z a n e k s e m. 1981a. Wieś Słopnice Królewskie. Krakowskie Biuro Geodezji i Terenów Rolnych w Krakowie, maszynopis. (in Polish)

Mapa glebowo-rolnicza w skali 1:5000 wraz z a n e k se m. 1981b. Wieś Słopnice Szlacheckie. Krakowskie Biuro Geodezji i Terenów Rolnych w Krakowie, maszynopis. (in Polish)

Mirek Z., Piękoś-Mirkowa H., Zając A., Zając M. 2002. Vascular plants and pteridophytes of Poland. A checklist. W. Szafer Institute of Botany, Polish Academy of Sciences Kraków: 442.

Pawłowski F. 1972. Skład i budowa zbiorowisk roślinnych oraz metody ich badania. [In:] Szata roślinna Polski. Wł., Szafer, K., Zarzycki (ed.). Państwowe Wydawnictwo Naukowe, Warszawa, 1: 237-269. (in Polish)

Roschewitz I., Gabriel D., Tschrantke T., Thies C. 2005. The effects of landscape complexity on arable weed species diversity in organic and conventional farming. J. Appl. Ecol. 42: 873-882. http://dx.doi. org/10.1111 / j.1365-2664.2005.01072.x

Rozporządzenie Rady (WE) nr 834/2007 z dnia 28 czerwca 2007 r. w sprawie produkcji ekologicznej i znakowania produktów ekologicznych uchylające rozporządzenie (EWG) nr 2092/91. / Council Regulation (EC) No 834/2007 of 28 June 2007 on organic production and labelling of organic products and repealing Regulation (EEC) No 2092/9. (Dz. U. L. 189 z 20.07.2007 r., s. 1, z późn. zm.). (in Polish)

Rozporządzenie Komisji (WE) nr 889/2008 z dnia 5 września 2008 r. ustanawiające szczegółowe zasady wdrażania rozporządzenia Rady (WE) nr 834/2007 w sprawie produkcji ekologicznej i znakowania produktów ekologicznych w odniesieniu do produkcji ekologicznej, znakowania i kontroli. / Commission Regulation (EC) No 889/2008 of 5 September 2008 laying down detailed rules for the implementation of 
Council Regulation (EC) No 834/2007 on organic production and labelling of organic products with regard to organic production, labelling and control. (Dz. U. L. 250 z 18.09.2008 r., s. 1, z późn. zm.). (in Polish)

R z y mowska Z., Skrajna T.2011. Segetal flora of the $€ u-$ ków Plain. Acta Agrobot. 64(2): 93-108. http://dx.doi. org/10.5586\%2Faa.2011.021

Siciński J.T., Sieradzki J. 2010. Protection of segetal flora and vegetation in Poland (historical outline). Plant Breed. Seed Sci. 61: 123-131. http://dx.doi.org/10.2478/ v10129-010-0019-1

S ołt y s A. 2006. Rzadkie i zagrożone gatunki chwastów segetalnych w Ojcowskim Parku Narodowym i jego otulinie. / Rare and threatened segetal weeds in the Ojców National Park and its protection zone. Pam. Puław. 143: 173-181. (in Polish)

S t a $\mathrm{S}$ of t, Inc. (2011). STATISTICA (data analysis software system), version 10. www.statsoft.com.

Stupnicka-Rodzynkiewicz E. 1995. Zachwaszczenie upraw zbożowych w zależności od położenia pól w terenie górskim. / Plant communities of cereals with respect to the location of field in mountains region. Acta Agrobot. 48(1): 15-24. (in Polish)

Stupnicka-Rodzynkiewicz E., Hochół T. 2000. Fitocenozy zbóż w gospodarstwach ekologicznych na wybranych przykładach z terenu Małopolski. / Phytocenosis of cereals in ecological farms as shown on selected samples of Małopolska region. Pam. Puław. 122: 31-37. (in Polish)

Sutcliffe O.L., Kay Q.O.N. 2000. Changes in the arable flora of central southern England since the 1960s. Biol. Conserv. 93: 1-8. http://dx.doi.org/10.1016\%2FS 0006-3207\%2899\%2900119-6

Trzcińska-Tacik H. 2003a. Zmiany we florze chwastów polnych - ziół leczniczych na terenie doliny Wierzbanówki na Pogórzu Wielickim w latach 1979-2002. I Changes in the flora of segetal weeds - medicinal plants in the Wierzbanowka Valley (Wieliczka Foothills, Southern Poland) in 1979-2002. Pam. Puław. 134: 247 252. (in Polish)

Tr z c ińs k a - Ta c i k H. 2003b. Znaczenie różnorodności gatunkowej chwastów segetalnych. / Importance of field weeds species diversity. Pam. Puław. 134: 253-261. (in Polish)

Wa rcholińska A.U. 1994. List of threatened segetal plant species in Poland. [In:] S. Mochnacký, A. Terpó (eds). Anthropization and environment of rural settlements. Flora and vegetation. Proc. of International Conference. Sátoraljaújhely, 22-26 August 1994: 206-219.

Węgrzynek B. 2010. Differentiation of arable field weed communities in the northern part of Silesian Upland ( $\mathrm{S}$ Poland). Plant Breed. Seed Sci. 61: 85-92. http://dx.doi. org/10.2478/v10129-010-0015-5
Wójcik Z 1968. Udział apofitów i antropofitów w zbiorowiskach segetalnych Mazowsza. / The participation of apophytes and antropophytes in plant communities of cultivated fields in the Masovia Region. [In:] J.B. Faliński (ed.). Synantropizacja szaty roślinnej. I. Neofityzm i apofityzm. Mat. Zakł. Fitosocj. Stos. UW, WarszawaBiałowieża, 25: 109-124. (in Polish)

\section{Zróżnicowanie i stopień przeobrażenia flory chwastów w ekologicznych i ekstensywnych konwencjonalnych uprawach zbóż w wybranych siedliskach Beskidu Wyspowego}

\section{Streszczenie}

Celem pracy było określenie wpływu warunków produkcji, kształtowanych przez czynniki siedliskowe oraz system gospodarowania, na spektrum geograficzno-historyczne flory chwastów towarzyszących uprawom zbóż oraz wybrane aspekty jej przeobrażeń. Badania prowadzono w latach 2009-2011 w siedmiu siedliskach polnych na terenie gminy Słopnice (Beskid Wyspowy). Materiał badawczy stanowiły 192 zdjęcia fitosocjologiczne wykonane metodą Braun-Blanquet'a w ekologicznych i ekstensywnych konwencjonalnych uprawach zbóż. Uzyskane wyniki świadczą o niezależnej od warunków przewadze liczbowej w zachwaszczeniu gatunków rodzimych (spontaneofitów) nad taksonami obcego pochodzenia. Flora obcego pochodzenia jest zdominowana przez archeofity, wskazujące na historyczną ciągłość kultury rolnej obszaru badań. Dominujący udział we florze spontaneofitów synantropijnych (apofitów) świadczy o wiodącej roli procesu apofityzacji, a tym samym o małym wpływie antropopresji na stan i mierzalne przemiany flory.

Parametry opisujące synantropijne przeobrażenia flory polnej, tj. wskaźnik antropofityzacji, archeofityzacji, kenofityzacji oraz modernizacji flory nie wykazują istotnego zróżnicowania spowodowanegowarunkamiprodukcji.Istniejąjednak przesłanki pozwalające na domniemanie, że o kierunkach i nasileniu przeobrażeń flory segetalnej obszaru badań bardziej decydują warunki siedliskowe, które zapewniają trwałe współwystępowanie zróżnicowanych form użytkowania ziemi i zbiorowisk roślinnych, istotnych dla utrzymania różnorodności biologicznej i wzmacniających zrównoważenie środowiska rolniczego. 